\title{
PRODUCER FIGHT AGAINST CROWN GALL DISEASE
}

\author{
YAĞCI, A. \\ Department of Horticulture, Gaziosmanpaşa University, 60240 Tokat, Turkey \\ (e-mail: adem.yagci@gop.edu.tr; phone: +90-356-252-1486; fax: +90-356-252-1488) \\ (Received $1^{\text {st }}$ Mar 2018; accepted $10^{\text {th }}$ May 2018)
}

\begin{abstract}
Agrobacterium vitis-induced crown gall disease (tumor) is the greatest problem in vineyards. Much proceed has not been achieved in fight against crown gall disease. Producers either totally stub out the vines from already established vineyards or keep viticulture activities with palliative measures. This study was conducted for two years to investigate the effects of shoot regeneration on yield, quality and development of A. vitis-infected grapevines. Initially the grapevines with morphologic A. vitis symptoms were determined in experimental vineyard. Then, deep pruning (cutting) was performed $10-15 \mathrm{~cm}$ below the tumorous sections of the stems in 2010, 2011 and 2012 and shoot regeneration was stimulated. Data were gathered about yield, quality (number of clusters, cluster weight, berry weight, must TSS content, TA, maturation index) and vine growth parameters (number of buds, number of shoots, burst ratio, pruning weight). About $15 \%$ less development was observed in grapevines with shoot regeneration treatments in 2012, 25\% in grapevines with shoot regeneration treatments in 2011 and 37\% in grapevines with shoot regeneration treatments in 2010. With shoot regenerations in 2012, 2011 and 2010, yields decreased respectively by 49,58 and $66 \%$; cluster weights decreased respectively by 32,37 and $47 \%$ and berry weights decreased respectively by 14,19 and $21 \%$.
\end{abstract}

Keywords: pruning, Narince, yield, development, percent change

\section{Introduction}

The yield and quality in viticulture are largely dominated by the rootstocks, training systems, irrigation methods, fertilization and relevant technical and cultural practices (Winkler et al., 1974; Çelik et al., 1998; Noar and Gal, 2002; Keller, 2010). Pests and disease management is also another factor significantly influencing yield and quality in viticulture. It was reported that without the proper control practices, $66 \%$ yield loss was caused by powdery mildew (Çetinkaya and Onoğur, 2006) and 10-15\% yield loss was caused by dead-arm (Phomopsis viticola) (Anonymous, 2013). Pest and diseases result in significant changes in number of clusters, cluster weights, berry weights and physicochemical attributes of the berries (Pool et al., 1984; Stummer et al., 2003; Akgül et al., 2017).

Pests and disease prevention and control measures are not either taken or such measures are uneconomic in vineyards. Common pests and diseases include bacterial crown gall (crown gall disease) (Agrobacterium vitis or Rhizobium vitis), Eutypa (Eutypa lata), viral infections (Grapevine Leafroll, Grapevine Fanleaf) and phylloxera pest (Viteus vitifoliae). Crown gall (A. vitis) disease is a bacterial disease (Ophel and Kerr, 1990). Disease progress is closely related to climate conditions. The disease result is significant yield and quality losses in grapevines (Schroth et al., 1988; Çelik et al., 2000; Diana and Dejeu, 2011; Akgül et al., 2016).

A. vitis is transported through xylem and phloem transportation vessels (Lehoczky, 1971; Burr et al., 1998). The bacterium usually causes tumor formations over grapevine stem. The disease also encountered in roots and shoots (Lehoczky, 1971; Burr et al., 1987; Keller, 2010). The tumors formed over various parts of the plant limit water and nutrient transport throughout the plant. Then vine growth and development, yield and quality decreases in time (Schroth et al., 1988; Ferreira et al., 1992; Keller, 2010; Diana 
and Dejeu, 2011). Scrapping the tumors over the stem and 5-7\% Bordeaux mixture applications over the lesions (Saygill et al., 2008) may prolong grapevine life for couple years, but cannot prevent ultimate deaths (Burr and Katz, 1984; Schroth et al., 1988).

In present research region, $75.35 \%$ of the vineyards are infected with A. vitis (Durak et al., 2017). Therefore, farmers are still making productions with generally infected grapevines. Some producers cut A. vitis-infected grapevines $10 \mathrm{~cm}$ below the tumors and apply high concentration (7-8\%) Bordeaux mixture over the lesion. Then, adventive buds over the stem shoot out and new shoots are formed (Figs. 1 and 2). Such a practice is shortly defined as shoot regeneration.

This study was conducted to investigate the effects of shoot regeneration treatments on grape yield, quality and development of A. vitis-infected grapevines.

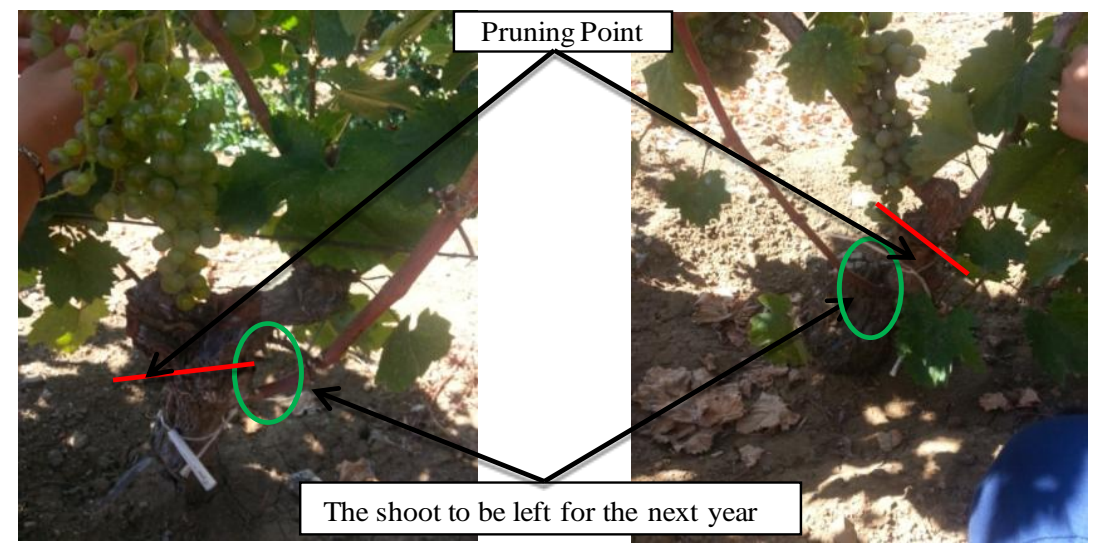

Figure 1. The grapevines to be shoot regenerated in the next year: pruning locations and the shoots to be left

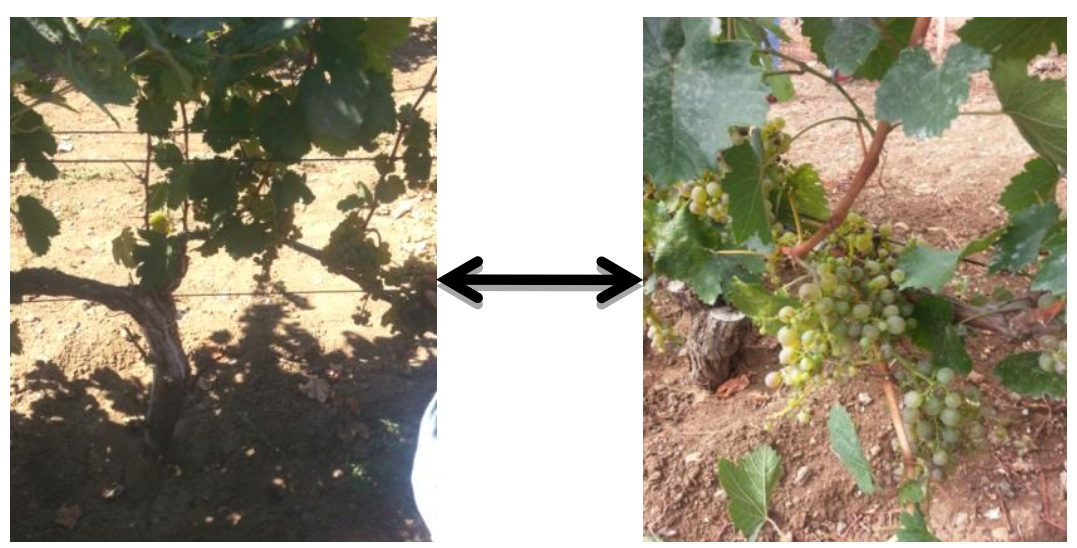

Figure 2. Shoot regenerated in 2013 (harvest time of 2013)

\section{Materials and methods}

Experiments were conducted in a producer vineyard (Tokat-Turkey; located at $40^{\circ}$ $37^{\prime} 10.99^{\prime \prime} \mathrm{N}, 36^{\circ} 43^{\prime} 27.87^{\prime \prime}$ E) in 2013 and 2014. Narince/1103 Paulsen grape cultivar planted at $3.0 \times 1.5 \mathrm{~m}$ planting density in 2000 was used as the plant material. Narince is a significant white wine cultivar of Turkey. International Vitis code of the cultivar is 8351. Bilateral cordon system was used as training system. Dry farming was practiced 
without any irrigations. Standard care practices were performed throughout the experiments.

The first A. vitis symptoms were observed by the owner in 2008. From the year 2010, severe/deep pruning was performed $10-15 \mathrm{~cm}$ below tumorous section of the grapevine stem (Figs. 1 and 2). This process was kept on in 2011 and 2012. New shoots of the grapevines were long-pruned (10-12 buds) in the second year. The grapevines with shoot regeneration treatments were marked in each year. Brief information about the grapevines considered in this study is provided in Table 1.

Table 1. Stem regeneration year, stem diameter and number of grapevines

\begin{tabular}{|c|c|c|}
\hline Stem regeneration year & Stem diameter (mm) & Number of grapevines \\
\hline Non-tumorous (2000) & $78.0-82.0 \mathrm{~mm}$ & 6 \\
\hline GY-1 (year 2012) & $13.0-19.0 \mathrm{~mm}$ & 6 \\
\hline GY-2 (year 2011) & $15.0-20.0 \mathrm{~mm}$ & 6 \\
\hline GY-3 (year 2010) & $15.0-22.0 \mathrm{~mm}$ & 6 \\
\hline
\end{tabular}

Experiments were conducted in 2013 and 2014. Therefore, the time elapsed between shoot regeneration and yielding years in grapevines with stem regeneration in 2010, 2011 and 2012 was expressed as: 1-2 years (GY-1) (for 2012), 2-3 years (GY-2) (for 2011) and 3-4 years (GY-3) (for 2010).

In 2013, pathogen existence and diagnosis analysis was performed in experimental vineyard. A. vitis pathogen was diagnosed in all of the shoot-regenerated grapevines. For diagnosis; DNA extractions were performed in accordance with Benlioğlu et al. (1998) and PCR tests were performed in accordance with Szegedi and Bottka (2002). Within the same vineyard, the grapevines without tumor development and with negative analysis results were considered as control vines.

\section{Methods}

Development, yield and some quality parameters were measured on grapevines.

\section{Development values}

Number of buds: The buds left over the grapevines were counted after pruning (Eq. 1).

Number of shoots: The shoots in each grapevine were counted.

$$
\text { Burst ratio }(\%)=\left(\frac{\text { Number of bursted buds }}{\text { Total number of buds }}\right) \times 100
$$

Pruning weight (kg/vine): Pruning was performed after defoliation and 1-year-old wood (shoot) were weighted.

\section{Yield and quality values}

Harvest was performed at The Soluble Solid (TSS) contents of between 19.0-23.0\% (Rieger, 2006). 
Yield (kg/vine): The grapes harvested from each vine were weighted with a digital balance (Densi PC-300) to get the yield per vine.

Number of clusters (cluster/vine): Clusters were counted at harvest.

Cluster and berry weights $(\mathrm{g})$ were determined with a digital balance (Precisa BJ 1200C); TSS contents were determined with a refractometer (Atago Master-93H); must $\mathrm{pH}$ values were determined with a $\mathrm{pH}$ meter (WTW Inolab $\mathrm{pH} 7310$ ); titratable acid (TA) (g/l) was measured in accordance with Cemeroğlu (1992); maturation index was calculated as TSS/TA ratio.

\section{Statistical analysis}

Experiments were designed in randomized plots with six replications. Descriptive statistics for the continuous variables were presented as Mean and Standard Error of Mean while count and percentages for categorical variables. One-way ANOVA was used to compare group means. LSD multiple comparison test was performed to identify different group means followed by ANOVA. Statistical significance level was considered as 5\% and SPSS (ver: 13) statistical program was used for all statistical computations.

Percent change: Percent change in investigated parameters indicates positive or negative changes in data as compared to the control. Percent changes were calculated by using Equation 2.

$$
\text { Percent Change }=\left(\frac{\text { Control }}{\text { Treatment }}-1\right) \times 100
$$

\section{Results and discussion}

\section{Development values}

In observations made at the period in which inflorescences were started to be seen, number of buds left per vine, number of shoots and pruning weights were significantly different in both years, but the differences in bursting ratios were not found to be significant. Pruning weight is a significant indicator of vine growth and development and the values were higher in healthy grapevines. Pruning weights proportionally decreased with the shoot age. In other words, the grapevines with earlier shoot regeneration were more influenced by disease severity. Such a case then regressed vine development (Tables 2 and 3). When the vine growth in healthy vines are assumed to be 100, the development values in 2013 and 2014 were respectively 19-15\% less in GY-1, $26-25 \%$ less in GY-2, 41-37\% less in GY-3.

Table 2. Effects of shoot regeneration on vine growth and development (year 2013)

\begin{tabular}{c|c|c|c|c}
\hline $\begin{array}{c}\text { Shoot regeneration } \\
\text { year }\end{array}$ & Number of buds & Number of shoots & $\begin{array}{c}\text { Bud burst (\%) } \\
(\boldsymbol{E q} \text {. 1) }\end{array}$ & $\begin{array}{c}\text { Pruning weight } \\
\text { (kg/vine) }\end{array}$ \\
\hline Control & $25.5 \pm 2.1 \mathrm{a}$ & $22.3 \pm 2.4 \mathrm{a}$ & $88 \pm 2.8 \mathrm{a}$ & $2.29 \pm 0.3 \mathrm{a}$ \\
$\mathrm{GY}-1$ & $21.2 \pm 0.8 \mathrm{bc}$ & $17.7 \pm 1.1 \mathrm{~b}$ & $84 \pm 3.2 \mathrm{~b}$ & $2.08 \pm 0.3 \mathrm{ab}$ \\
$\mathrm{GY}-2$ & $19.7 \pm 1.2 \mathrm{c}$ & $15.8 \pm 1.4 \mathrm{~b}$ & $81 \pm 2.6 \mathrm{bc}$ & $1.78 \pm 0.4 \mathrm{bc}$ \\
$G Y-3$ & $22.0 \pm 0.9 \mathrm{~b}$ & $16.8 \pm 1.1 \mathrm{~b}$ & $77 \pm 3.2 \mathrm{c}$ & $1.580 \pm 0.4 \mathrm{c}$ \\
$\mathrm{LSD}_{(0.05)}$ & 1.7 & 2.1 & 3.7 & 0.4 \\
\hline
\end{tabular}


Table 3. Effects of shoot regeneration on vine growth and development (year 2014)

\begin{tabular}{c|c|c|c|c}
\hline $\begin{array}{c}\text { Shoot regeneration } \\
\text { year }\end{array}$ & $\begin{array}{c}\text { Number of } \\
\text { buds }\end{array}$ & Number of shoots & $\begin{array}{c}\text { Bud burst (\%) } \\
(\boldsymbol{E q} . \mathbf{~})\end{array}$ & $\begin{array}{c}\text { Pruning weight } \\
\text { (kg/vine) }\end{array}$ \\
\hline Control & $26.5 \pm 2.7 \mathrm{a}$ & $23.0 \pm 2.2 \mathrm{a}$ & $87 \pm 1.8$ & $3.33 \pm 0.4 \mathrm{a}$ \\
GY-1 & $24.7 \pm 1.7 \mathrm{~b}$ & $21.2 \pm 1.1 \mathrm{~b}$ & $86 \pm 2.6$ & $2.70 \pm 0.2 \mathrm{~b}$ \\
GY-2 & $24.5 \pm 2.5 \mathrm{~b}$ & $21.2 \pm 2.7 \mathrm{~b}$ & $86 \pm 2.7$ & $2.46 \pm 0.3 \mathrm{~b}$ \\
GY-3 & $21.2 \pm 1.7 \mathrm{c}$ & $17.8 \pm 1.4 \mathrm{c}$ & $85 \pm 2.8$ & $1.98 \pm 0.4 \mathrm{c}$ \\
LSD $_{(0.05)}$ & 2.9 & 2.9 & NS & 0.4 \\
\hline
\end{tabular}

\section{Yield and quality values}

The grapevines subjected to shoot regenerations due to A. vitis had significantly different yield and quality values from the healthy vines. With regard to yield, number of cluster, cluster weight, berry weight and maturation index values, while healthy vines were placed in one group, shoot-regenerated vines were placed in two different groups. The lowest values were observed in the oldest shoot-regenerated (year 2010) vines (Tables 4 and 5).

Table 4. Effects of shoot regeneration on grapevine yield and quality (year 2013)

\begin{tabular}{c|c|c|c|c|c|c|c|c}
\hline Treatment & $\begin{array}{c}\text { Yield } \\
(\mathbf{k g} / \text { vine })\end{array}$ & $\begin{array}{c}\text { Number of } \\
\text { clusters }\end{array}$ & $\begin{array}{c}\text { Cluster } \\
\text { weight }(\mathbf{g})\end{array}$ & $\begin{array}{c}\text { 100 berry } \\
\text { weight }(\mathbf{g})\end{array}$ & TSS $(\%)$ & pH & TA (g/l) & $\begin{array}{c}\text { Maturation } \\
\text { index }\end{array}$ \\
\hline Control & $6.57 \pm 0.7 \mathrm{a}$ & $21.3 \pm 2.3 \mathrm{a}$ & $308 \pm 15 \mathrm{a}$ & $309 \pm 12 \mathrm{a}$ & $21.6 \pm 1.1$ & $2.84 \pm 0.12 \mathrm{ab}$ & $5.82 \pm 0.14 \mathrm{~b}$ & $35.5 \pm 2.5 \mathrm{a}$ \\
$\mathrm{GY}-1$ & $3.48 \pm 0.3 \mathrm{~b}$ & $15.2 \pm 1.7 \mathrm{~b}$ & $229 \pm 18 \mathrm{~b}$ & $236 \pm 35 \mathrm{~b}$ & $19.5 \pm 1.5$ & $2.64 \pm 0.21 \mathrm{c}$ & $7.21 \pm 0.84 \mathrm{a}$ & $27.5 \pm 4.6 \mathrm{~b}$ \\
$\mathrm{GY}-2$ & $2.79 \pm 0.4 \mathrm{c}$ & $13.3 \pm 1.2 \mathrm{bc}$ & $210 \pm 29 \mathrm{~b}$ & $251 \pm 32 \mathrm{~b}$ & $19.6 \pm 0.8$ & $2.91 \pm 0.15 \mathrm{a}$ & $6.63 \pm 0.54 \mathrm{a}$ & $29.7 \pm 2.9 \mathrm{~b}$ \\
$\mathrm{GY}-3$ & $2.18 \pm 0.5 \mathrm{c}$ & $13.0 \pm 1.4 \mathrm{c}$ & $166 \pm 25 \mathrm{c}$ & $226 \pm 13 \mathrm{~b}$ & $19.4 \pm 1.2$ & $2.66 \pm 0.22 \mathrm{bc}$ & $7.05 \pm 0.71 \mathrm{a}$ & $27.8 \pm 2.8 \mathrm{~b}$ \\
$\mathrm{LSD}_{(0.05)}$ & 0.65 & 2.1 & 26.7 & 28.3 & $\mathrm{NS}$ & 0.2 & 0.8 & 4.0 \\
\hline
\end{tabular}

Table 5. Effects of shoot regeneration on grapevine yield and quality (year 2014)

\begin{tabular}{c|c|c|c|c|c|c|c|c}
\hline Treatment & $\begin{array}{c}\text { Yield } \\
\text { (kg/vine) }\end{array}$ & $\begin{array}{c}\text { Number of } \\
\text { clusters }\end{array}$ & $\begin{array}{c}\text { Cluster } \\
\text { weight }(\mathbf{g})\end{array}$ & $\begin{array}{c}\text { 100 berry } \\
\text { weight }(\mathbf{g})\end{array}$ & TSS (\%) & pH & TA (g/l) & $\begin{array}{c}\text { Maturation } \\
\text { index }\end{array}$ \\
\hline Control & $8.82 \pm 0.7 \mathrm{a}$ & $25.5 \pm 1.8 \mathrm{a}$ & $347 \pm 25 \mathrm{a}$ & $305 \pm 26 \mathrm{a}$ & $2.30 \pm 0.7 \mathrm{a}$ & $3.39 \pm 0.2$ & $6.39 \pm 0.3$ & $33.5 \pm 2.8$ \\
GY-1 & $4.40 \pm 0.5 \mathrm{~b}$ & $18.7 \pm 2.1 \mathrm{~b}$ & $217 \pm 16 \mathrm{~b}$ & $295 \pm 42 \mathrm{ab}$ & $20.76 \pm 1.2 \mathrm{a}$ & $3.56 \pm 0.1$ & $7.80 \pm 1.2$ & $27.3 \pm 4.7$ \\
GY-2 & $3.71 \pm 0.7 \mathrm{bc}$ & $18.7 \pm 2.5 \mathrm{~b}$ & $201 \pm 38 \mathrm{~b}$ & $275 \pm 22 \mathrm{ab}$ & $19.04 \pm 1.5 \mathrm{~b}$ & $3.60 \pm 0.1$ & $7.55 \pm 1.0$ & $25.9 \pm 5.2$ \\
GY-3 & $3.11 \pm 0.9 \mathrm{c}$ & $16.8 \pm 11 \mathrm{~b}$ & $184 \pm 47 \mathrm{~b}$ & $261 \pm 39 \mathrm{~b}$ & $20.36 \pm 1.6 \mathrm{ab}$ & $3.56 \pm 0.1$ & $6.85 \pm 1.4$ & $31.3 \pm 5.7$ \\
$\mathrm{LSD}_{(0.05)}$ & 0.9 & 2.3 & 43.7 & 35.5 & 1.4 & $\mathrm{NS}$ & $\mathrm{NS}$ & $\mathrm{NS}$ \\
\hline
\end{tabular}

When the shoot-regenerated vines were compared with the healthy vines, it was observed that yield values in 2013 and 2014 respectively decreased by $47-50 \%$ in GY-1, $58-58 \%$ in GY-2 and 67-64\% in GY-3.

According to two-year averages, grape yield of healthy vines was $7.70 \mathrm{~kg}$, cluster weight was $328 \mathrm{~g}, 100$ berry weight was $307 \mathrm{~g}$ and pruning weight was $2.81 \mathrm{~kg} / \mathrm{vine}$. In shoot-regenerated grapevines, grape yields varied between $2.65-3.94 \mathrm{~kg}$, cluster weights varied between 175-223 g, 100 berry weights varied between 244-266 g and pruning weights varied between $1.78-2.39 \mathrm{~kg} / \mathrm{vine}$. Regression analyses revealed continuous 
decrease in yield, cluster weight, berry weight and pruning weights with the years. Such decreases were found to be significant in all four parameters (Fig. 3a-d).

According to two-year averages, as compared to control treatments, percent change in yield and quality parameters of $A$. vitis-infected oldest shoot-regenerated grapevines was quite greater than the other vines (Fig. 4).

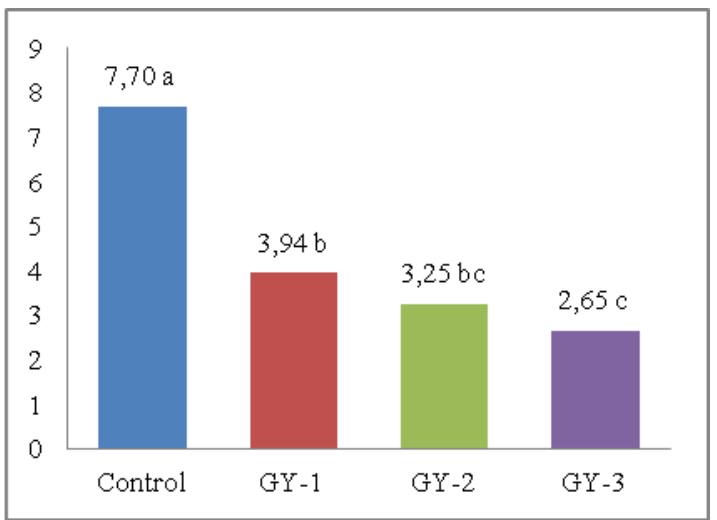

$\mathbf{a}$

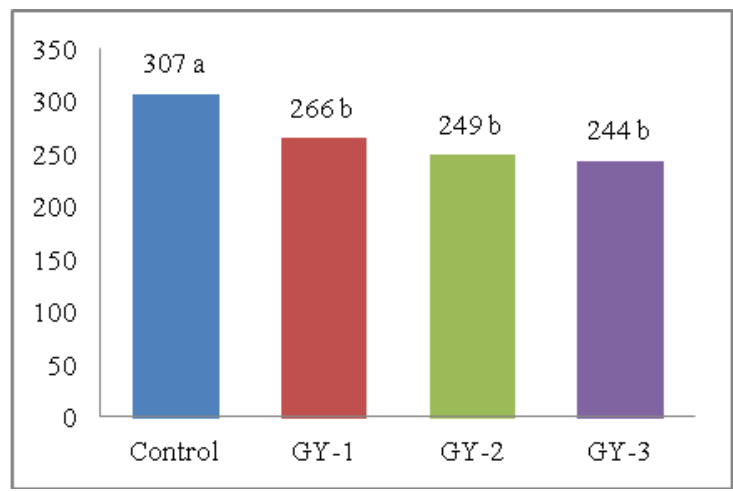

c
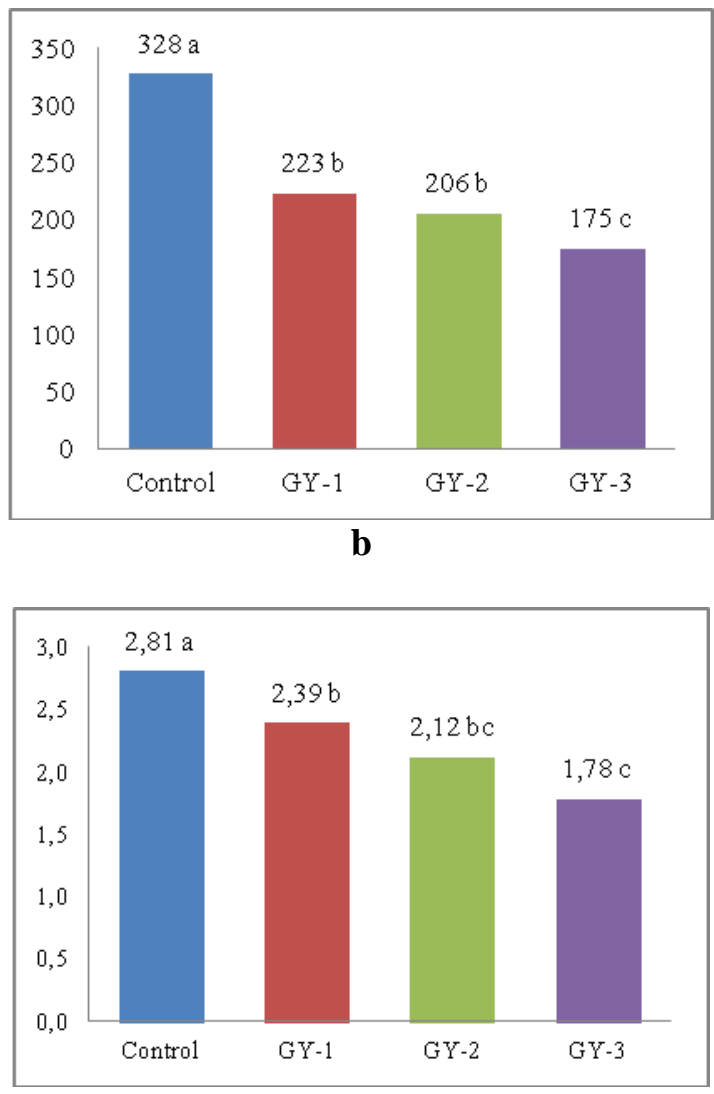

d

Figure 3. a: Average yield values based on shoot regeneration years $(\mathrm{kg} /$ vine $)\left(L S D_{0.05}=0.8\right)$. $b$ : Average cluster weights based on shoot regeneration years $(g)\left(L S D_{0.05}=24.1\right)$. c: Average 100 berry weights based on shoot regeneration years $(g)\left(L S D_{0.05}=26.1\right) . d$ : Average pruning weight based on shoot regeneration years $(\mathrm{kg} /$ vine $)\left(L S D_{0.05}=0.41\right)$

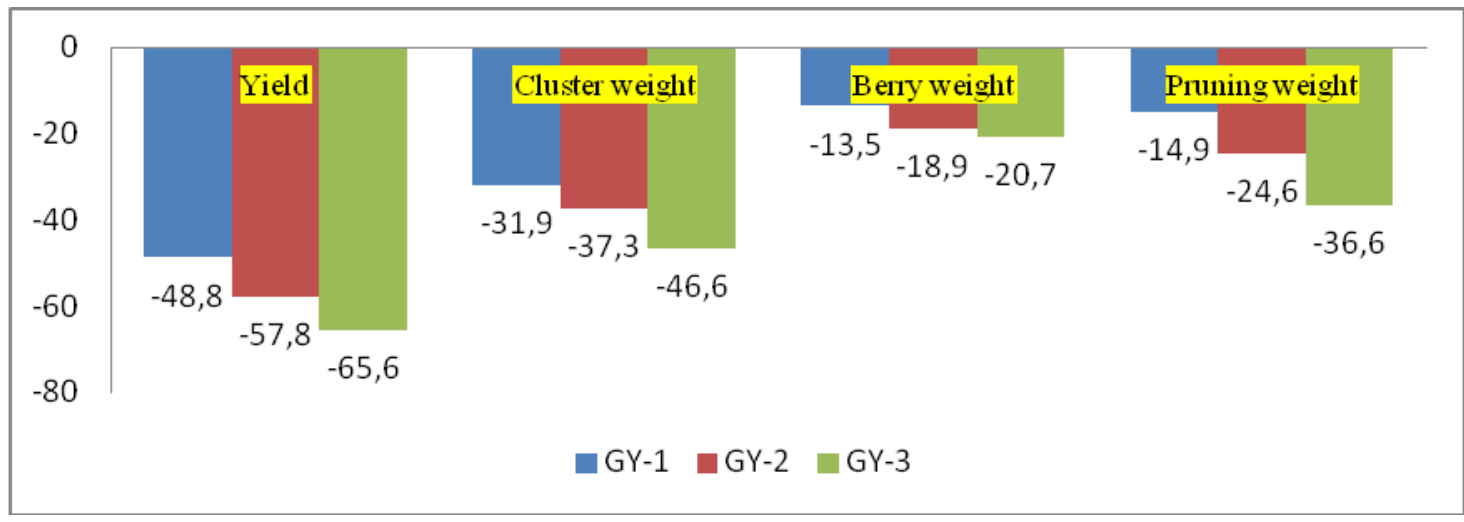

Figure 4. Percent change in yield and quality parameters of shoot-regenerated grapevines as compared to the control vines (Eq. 2) 
Present findings on A. vitis-induced decreases in yield, growth and development of grapevines comply with the results of Schroth et al. (1988) and Ferreira et al. (1992). Negative trends in changes in infected grapevines (yield, number of clusters, cluster weight, berry weight, TTS and TA) were mostly resulted from growth weakening effect of $A$. vitis.

Pruning weight is a significant indicator of grapevine growth and development (Noar and Gal, 2002; Çelik and Çağdaş, 2007; Keller, 2010). With the weakening in vine growth and development, especially carbohydrate mechanism of the grapevines is negatively influenced (A ğaoğlu, 2002; Keller, 2010) and resultant tumors significantly limit or restrict nutrient transport through various parts of the plants (Lehoczky, 1971; Burr et al., 1998).

\section{Conclusion}

Producers usually try or employ various methods to overcome the problems they experienced in viticulture practices. Significant $A$. vitis-induced decreases in yield and quality parameters were also reported by the growers. Instead of totally stubbing already established vineyard and waiting 4-5 years to reestablish the new one, deep pruning for shoot regeneration and to rejuvenate the grapevines may provide a practical solution for A. vitis-infected grapevines. However, such practices can only serve a short-term solution, may prolong vine life and allow growers to get yields for couple more years. A. vitis-infected vines ultimately end up with total die outs. For now, in present fight, the winner is still $A$. vitis ...

\section{REFERENCES}

[1] Ağaoğlu, Y. S. (2002): Theoretical and Applications in Viticulture (Vine Physiology-I). Kavaklidere Education Publ. No. 5., Ankara, Turkey.

[2] Akgül, D. S., Özyilmaz, Ü., Önder, S., Benlioğlu, K., Çelik, Ş., Soltekin, R. O. (2016): Molecular Characterization of Rhizobium Vitis, a Causal Agent of Grapevine Gall Disease, in the Aegean Region Vineyards and Sensitivity of Common Grapevine Rootstocks and Cultivars to Disease. - Turkey $6^{\text {th }}$ Plant Protection Congress, 5-8 September 2016, Konya, Turkey.

[3] Akgül, D. S., Önder, S., Merken, Ö., Kesgin, M., Yağc1, A. (2017): Effects of fungicide spray programs on Grapevine powdery and downy mildew diseases control and some quality criteria of Cardinal and Sultana Seedless grapes. - Bitki Koruma Bülteni 57(3): 373-390.

[4] Anonymous (2013): http://www.entofito.com/phomopsis-viticola/

[5] Benlioğlu, K., Özakman, M. (1998): Detection of crown gal agent (Agroba.cterium tumefaciens) in grapevine propagating material. - Turk J Agric For 22: 167-174.

[6] Burr, T. J., Katz, B. H. (1984): Grapevine cuttings as potential sites of survival and means of dissemination of Agrobacterium tumefaciens. - Plant Dis 68: 976-978.

[7] Burr, T. J., Katz, B. H., Bishop, A. L. (1987): Population of Agrobacterium in vineyard and nonvineyard soils and grape roots in vineyard and nurseries. - Plant Dis 71: 617-620.

[8] Burr, T. J., Bazzi, C., Süle, S., Otten, L. (1998): Crown gall of grape: Biology of Agrobacterium vitis and the development of disease control strategies. - Plant Dis 82: 1288-1297. 
[9] Çelik, H., Çağdaş, H. A. (2007): Effects of Training, Pruning Severity and Limited Irrigation before Veraison on Growth, Yield and Quality of Kalecik Karas1 Clones Grown in Central North of Anatolia. - The $8^{\text {th }}$ International Symposium on Grapevine Physiology and Biotechnology, Adelaide, Australia.

[10] Çelik, H., Ağaoğlu, Y. S., Fidan, Y., Marasalı, B., Söylemezoğlu, G. (1998): General Viticulture. - Sunfidan A. Ş., Ankara, Turkey.

[11] Çelik, H., Marasalı, B., Söylemezoğlu, G., Tangolar, S., Gündüz, M. (2000): Bağc1lıkta üretim hedefleri. - Türkiye Ziraat Mühendisliği V. Teknik Kongresi Bildirileri, Ankara, (Cilt 2), pp. 645-678.

[12] Cemeroğlu, B. (1992): Fundamental Analysis Methods of Fruit and Vegetable Processing Industry. - Biltav Publication No. 2, Ankara, Turkey.

[13] Çetinkaya, N., Onoğur, E., (2006): Effect of fertilization programs on the powdery mildew incidence and yield in organic Round Seedless vineyards. Ege Journal of Agricultural Research, 43 (1): 33-44.

[14] Diana, V., Dejeu, L. (2011): Crown gall (Agrobacterium spp.) and grapevine. - Journal of Horticulture, Forestry and Biotechnology 15(1): 130-138.

[15] Durak, H., Belgüzar, S., Cangi, R., Yanar, R. (2017): Prevalence and Characterization of Crown Gall Disease Agent Rhizobium vitis in Vineyards of Tokat Province. Gaziosmanpasa Journal of Scientific Research6 (3): 73-84.

[16] Ferreira, J. H. S., Zyl, F. G. H., Staphorst, J. L. (1992): Agrobacterium tumefaciens biovar 3 responsible for reduction in yield and vigour of Muscat d'Alexandrie. - S. Afr. J. Enol. Vitic. 13(2): 78-80.

[17] Keller, M. (2010): The Science of Grapevine: Anatomy and Physiology. - Academic Press of Elsevier, USA.

[18] Lehoczky, J. (1971): Further evidences concerning the systemic spreading of Agrobacterium tumefaciens in the vascular system of grapevines. - Vitis 10: 215-221.

[19] Noar, A., Gal, Y. (2002): Shoot and cluster thinning influence vegetative growth, fruit, yield, and wine quality of 'Sauvignon Blanc' grapevines. - J. Amer. Soc. Hort. Sci. 127(4): 628-634.

[20] Ophel, K., Kerr, A. (1990): Agrobacterium vitis sp. Nov. For Strains of Agrobacterium Biovar 3 From Grapevines. - International Journal of Systematic Bacteriology 40: 236241.

[21] Pool, R. M., Pearson, R. C., Welser, M. J., Lakso, A. N., Seem, R. C. (1984): Influence of powdery mildew on yield and growth of Rosette grapevines. - Plant Disease 68: 590-593.

[22] Rieger, M. (2006): Introduction to Fruit Crops. Grape (Vitis spp). - Haworth Press, Binghamton, New York.

[23] Saygıl1, H., Şahin, F., Aysan, Y. (2008): Plant Bacterial Diseases. - Meta Basım Matbaacılık İşlemleri, İzmir, Turkey.

[24] Schroth, M. N., McCain, A. H., Foott, J. H., Huisman, O. C. (1988): Reduction in yield and vigor of grapevine caused by crown gall disease. - Plant Disease 72: 241-246.

[25] Stummer, B. E., Francis, I. L., Markides, A. J., Scott, E. S. (2003): The effect of powdery mildew infection of grape berries on juice and wine composition and on sensory properties of Chardonnay wines. - Australian Journal of Grape and Wine Research 9: 2839.

[26] Szegedi, E., Bottka, S. (2002): Detection of Agrobacterium vitis by polymerase chain reaction in grapevine bleeding sap after isolation on a semiselective medium. - Vitis 41 (1): 37-42.

[27] Winkler, A. J., Cook, J. A., Klieer, W. M., Lider, L. A. (1974): General Viticulture. University of California Press, Berkeley. 